\title{
Kenyamanan Termal dan Kepuasan Pengguna Ruang Kelas di Gedung Kampus ITSB
}

\author{
Firman Fadhly Adhi Risnandar ${ }^{1}$ \\ Arsitektur, Fakultas Teknik dan Desain, Institut Teknologi dan Sains Bandung, Deltamas, Indonesia
}

\begin{abstract}
Abstrak
Gedung Kampus ITSB merupakan salah satu gedung Kampus di Indonesia yang sudah memenuhi kriteria hijau dengan predikat "Gold" dari Green Building Council Indonesia (GBCI). Gedung kampus dirancang dengan banyak bukaan untuk pemanfaatan pengawaan alami. Di sisi lain, penggunaan perangkat aktif masih digunakan untuk penghawaan tersebut, seperti penggunaan Air Conditioning (AC). Dalam hal ini, pemanfaatan desain pasif gedung belum dimanfaatkan secara optimal. Penelitian ini bertujuan untuk mengukur kinerja desain pasif gedung Kampus ITSB. Metode yang digunakan melalui simulasi antara pengukuran termal dengan survey kuesioner. Hasil penelitian menunjukkan bahwa, kinerja desain pasif gedung Kampus ITSB melalui penghawaan alami berkontribusi dalam memberikan kenyamanan bagi pengguna ruang.
\end{abstract}

Kata-kunci: desain pasif, kenyamanan termal, sensasi termal, penghawaan alami, ventilasi

\section{PENDAhUluAN}

Kenyamanan termal ruangan merupakan salah satu aspek penting yang harus dipenuhi dalam merancang suatu bangunan. Terdapat dua pendekatan yang dapat dilakukan untuk memenuhi standar kenyamanan termal ruangan, yaitu melalui pemanfaatan perangkat aktif, dan pemanfaatan desain pasif. Pemanfaatan perangkat aktif merupakan cara untuk mempertahankan kenyamanan ruang dalam melalui pengkondisian buatan, seperti penerapan solar panel aktif pada bangunan hingga penggunaan Air Conditioning (AC). Sementara itu, pemanfaatan desain pasif merupakan cara dalam mengoptimalkan potensi iklim mikro pada bangunan seperti pengkondisian udara alami dalam upaya mempertahankan kenyamanan termal ruang dalam agar tetap baik. Prinsip dasar ini di antaranya dapat dilakukan melalui ventilation ${ }^{8)}{ }^{9)}$. Pengkondisian udara alami pada bangunan memang tidak dapat dirasakan secara langsung oleh pengguna ruang, karena hal itu tergantung dari kondisi lingkungan dan iklim mikro di sekitar bangunan. 
Pemanfaatan desain pasif pada bangunan dipengaruhi oleh beberapa parameter, di mana selain pengaruh iklim, juga dipengaruhi oleh desain fasad, dan psikologis atau lingkungan sosial ${ }^{3)}$. Sementara itu, preferensi pengguna ruang akan penggunaan perangkat aktif untuk mengondisikan ruangan cenderung tinggi ${ }^{11)}$, karena penggunaannya yang mudah disesuaikan dengan kondisi tubuh pengguna ruang. Pengguna ruang merupakan salah satu aspek yang dapat dijadikan sebagai ukuran tingkat kepuasan terhadap kenyamanan termal suatu ruangan ${ }^{2)}$.

Kenyamanan termal merupakan kondisi pikiran yang menggambarkan kepuasan akan lingkungan termal dan dinilai dengan evaluasi subjektif 2) 4). Kenyamanan termal dipengaruhi oleh temperatur udara, kelembaban udara, kecepatan pergerakan udara, ratarata temperatur radiasi, pakaian pengguna ruang dan tingkat aktivitas pengguna ruang ${ }^{2}$. Terdapat beberapa pendekatan untuk mengukur tingkat kepuasan pengguna ruang terhadap kenyamanan termal suatu ruangan, yaitu melalui pendekatan model Predicted Mean Vote (PMV) dan berdasarkan prosentase tingkat ketidakpuasaan akan suatu lingkungan atau predicted percentage of dissatisfied (PPD) ${ }^{2}{ }^{4}$. Model-model tersebut merupakan penilaian subjektif pengguna yang dinyatakan dalam tujuh skala sensasi termal, yaitu: sangat dingin (-3), dingin (-2), sedikit dingin (-1), netral/nyaman (0), sedikit hangat (1), hangat (2) dan panas $(3)^{2}$. Hal ini dapat dilakukan melalui simulasi antara pengkondisian suatu ruangan dengan pengguna ruang.

Penelitian ini bertujuan untuk mengukur dan mengevaluasi kinerja desain pasif gedung Kampus ITSB. Simulasi lapangan diperlukan untuk mengetahui efektifitas tipe bukaan bangunan dalam mengontrol kondisi termal di dalam ruangan dan pengaruhnya terhadap persepsi pengguna ruang ${ }^{6}$.

\section{METODE}

Pengukuran dalam penelitian ini dilakukan melalui simulasi di dalam kelas, terdiri dari R. 402 di lantai 4, R. 310, dan R. 302 di lantai 3 Kampus ITSB. Luas masing-masing kelas sekitar $72 \mathrm{~m} 2(8,4 \mathrm{~m}$ x 8,575 m). Ketiga ruang kelas tersebut merupakan kelas yang dapat dipakai untuk simulasi.

\subsection{Pengumpulan Data}

Terdapat dua fokus utama dalam penelitian ini, yaitu:

1. Pengukuran termal,

2. Survey kuesioner.

Pengukuran termal terdiri dari pengukuran temperatur udara di luar dan di dalam ruangan, kelembaban dan kecepatan angin. Pengukuran temperatur udara dan kelembaban menggunakan termometer bola basah dan bola kering. Kecepatan angin diukur dengan anemometer 4 in 1. 


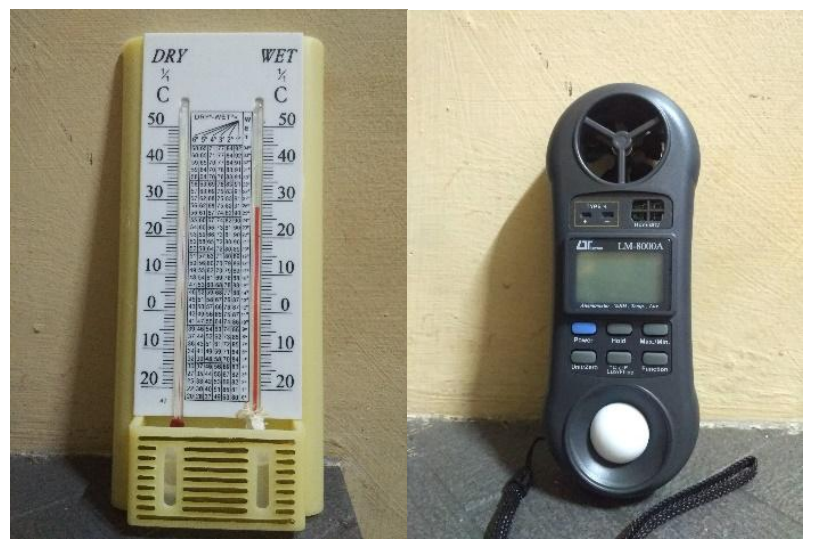

Gambar 1. Alat ukur termal: 1. Termometer bola basah bola kering, 2. Anemometer 4 in 1

Simulasi dibagi dalam beberapa sesi. Setiap sesi terdiri dari 40 orang responden. Terdapat sekitar 150 orang responden dalam simulasi ini, yang merupakan mahasiswa dan mahasiswi di Kampus ITSB. Para responden dikumpulkan di dalam ruang kelas, di mana ruang kelas dikondisikan dengan jendela terbuka tanpa menggunakan AC selama 15 menit. Waktu tersebut merupakan waktu minimal yang diperlukan untuk pengukuran berdasarkan standar ASHRAE ${ }^{2}$. Pengambilan data termal dalam rentang waktu tiga menit. Pada waktu yang bersamaan, para responden diberikan kuesioner untuk menilai kualitas termal ruang kelas tersebut.

Tabel 1. Deskripsi lokasi simulasi

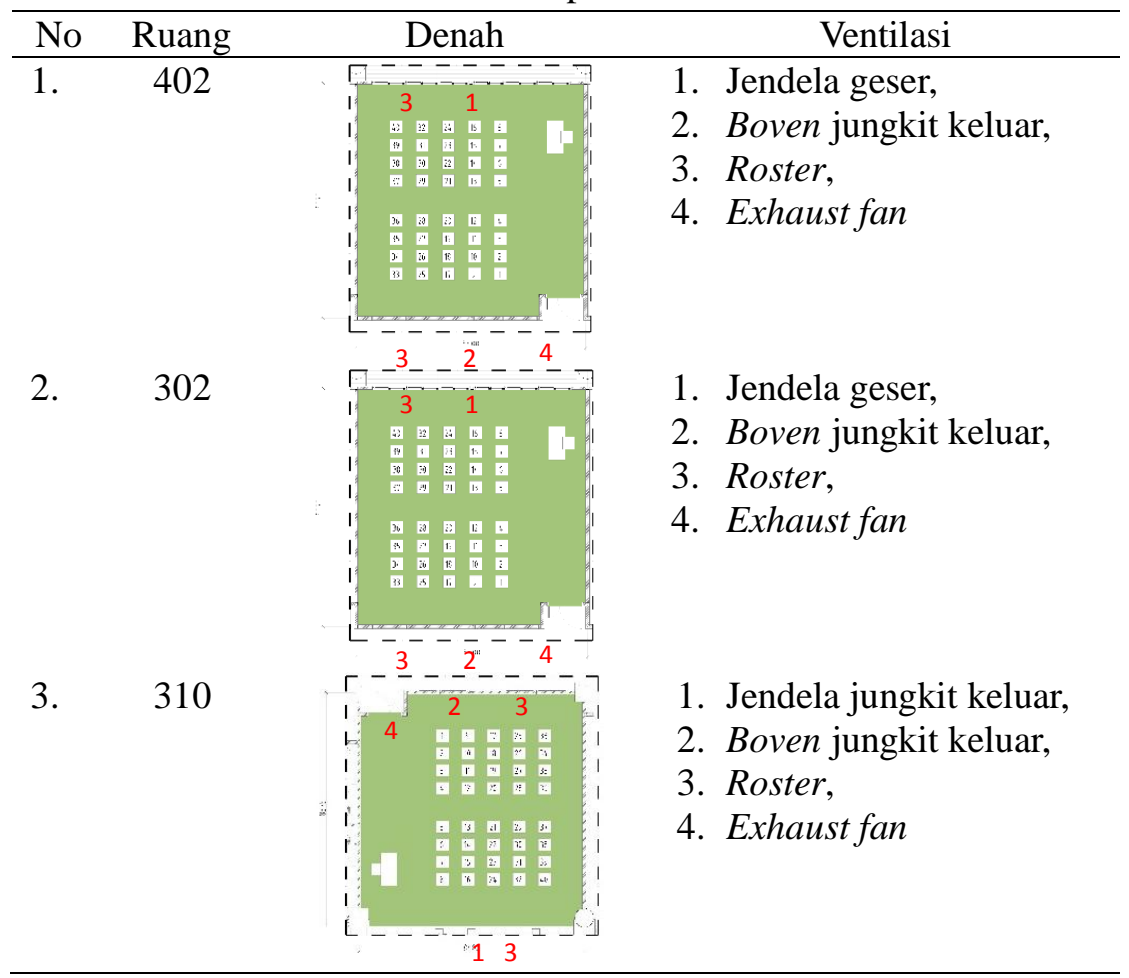




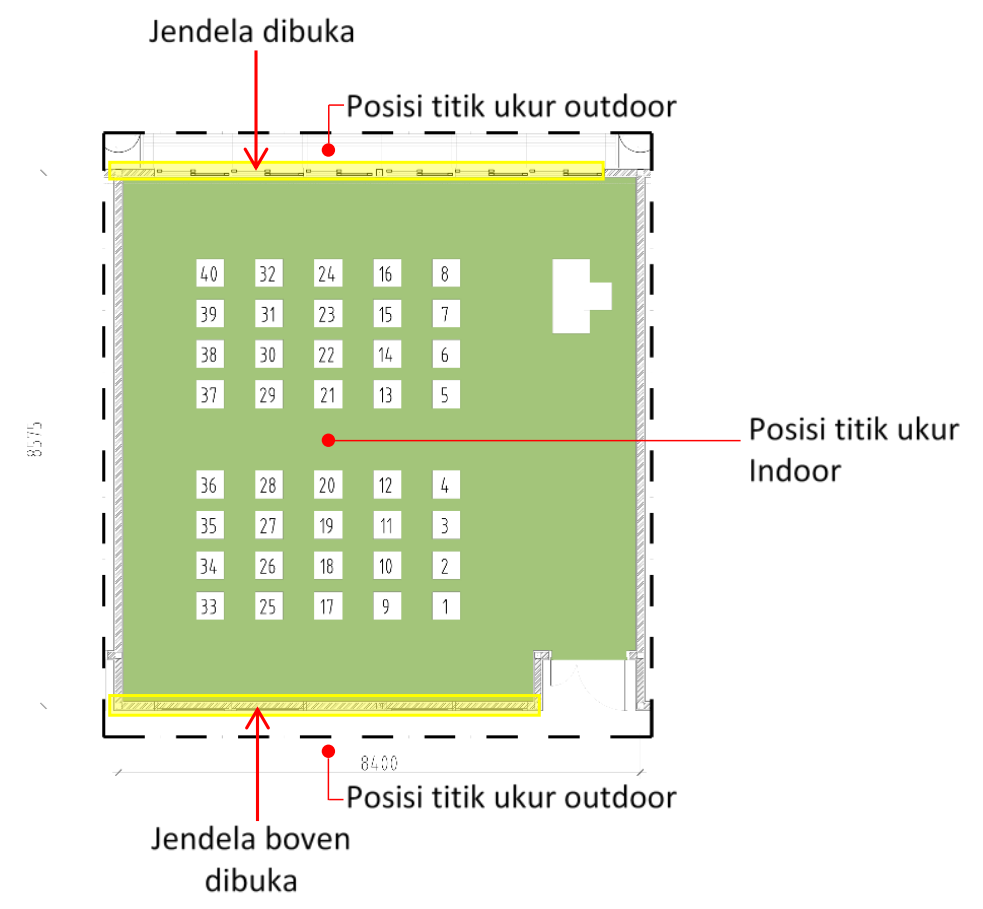

Gambar 2. Skema pengukuran termal dan survey kuesioner

\subsection{Analisis Data}

Data termal dan data kuesioner yang sudah dikumpulkan dianalisis dengan menggunakan analisis regresi linier menggunakan Microsoft Excel 2013. Analisis tersebut digunakan untuk mengidentifikasi Neutral Temperature (NT) dan pengaruh temperatur terhadap sensasi termal pengguna ruang atau Thermal Sensation Votes (TSV) ${ }^{1)}{ }^{5)}$ ) 7 .

\section{PEMBAHASAN DAN DISKUSI}

\subsection{Data Termal dan Kepuasan Responden di R. 402}

Data grafik berdasarkan Gambar 3, merupakan data temperatur udara rata-rata ruang dalam di R. 402 pada hari pertama pengukuran, pukul 11:00 WIB hingga pukul 11:15 WIB (Gambar 3). Hasil pengukuran menunjukkan temperatur udara rata-rata ruang sebesar $30,6^{\circ} \mathrm{C}$. Temperatur udara awal di dalam ruangan sebesar $30^{\circ} \mathrm{C}$, sedangkan temperatur tertinggi sebesar $31^{\circ} \mathrm{C}$, kelembaban sebesar $68 \%$. Kecepatan angin tertinggi sebesar 0,2 $\mathrm{m} / \mathrm{s}$ terjadi di area koridor. Pada kondisi tersebut, sebanyak delapan responden memilih 'sedikit hangat', enam responden memilih 'netral' dan enam responden lainnya memilih 'hangat' dari total 28 responden. Ini berarti, responden dominan cenderung merasakan sedikit ketidaknyamanan. 


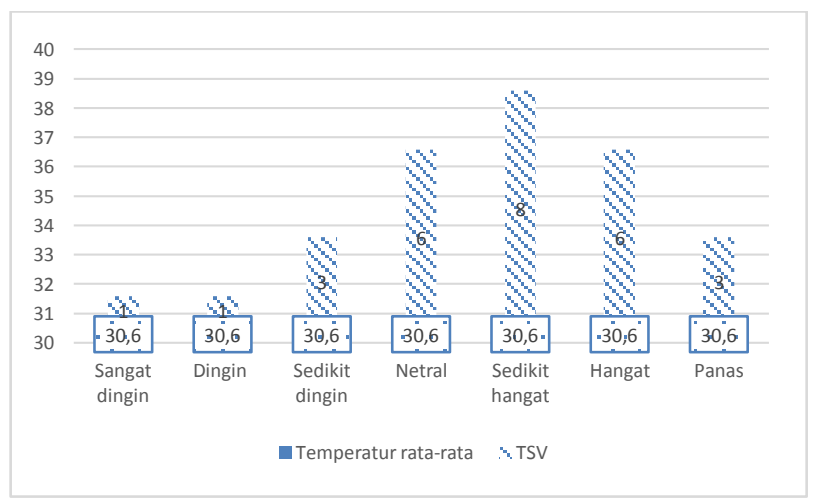

Gambar 3. Temperatur udara rata-rata dan TSV R. 402 pukul 11:00 WIB

Data grafik berdasarkan Gambar 4, merupakan data temperatur udara rata-rata ruang dalam, di R. 402 pada hari pertama pengukuran, pukul 13:15 WIB hingga pukul 13:30 WIB. Hasil pengukuran menunjukkan, temperatur udara rata-rata ruang sebesar $31,9^{\circ} \mathrm{C}$. Temperatur udara awal di dalam ruangan sebesar $31,6^{\circ} \mathrm{C}$, sedangkan temperatur tertinggi sebesar $32^{\circ} \mathrm{C}$. Kelembaban sebesar $62 \%$. Kecepatan angin fluktuatif, dengan kecepatan tertinggi sebesar $5 \mathrm{~m} / \mathrm{s}$ terjadi di area jendela boven. Sementara kecepatan angin di ruang kelas sebesar $0,5 \mathrm{~m} / \mathrm{s}$. Responden dominan memilih 'sedikit hangat' sebanyak 18 responden dari total 38 responden.

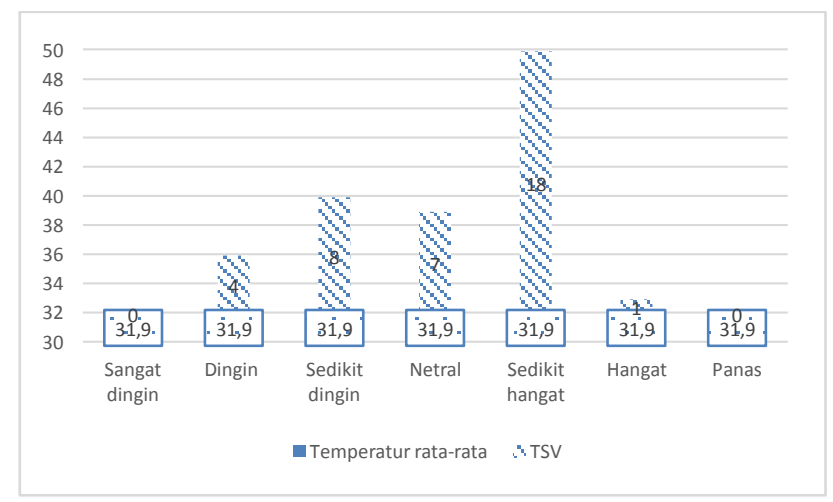

Gambar 4. Temperatur udara rata-rata dan TSV R. 402 pukul 13:15 WIB

Data grafik berdasarkan Gambar 5, merupakan data temperatur udara rata-rata ruang dalam, di R. 402 pada hari kedua, pukul 12:45 WIB hingga pukul 13:00 WIB. Hasil pengukuran menunjukkan, temperatur udara rata-rata ruang sebesar $32,4^{\circ} \mathrm{C}$. Temperatur udara awal di dalam ruangan sebesar $32^{\circ} \mathrm{C}$, sedangkan temperatur tertinggi sebesar $32,5^{\circ} \mathrm{C}$. Kelembaban sebesar 58\%. Kecepatan angin tertinggi sebesar 3,5 m/s terjadi di area koridor. Sementara untuk ruang kelas tidak ada pergerakan udara atau $0 \mathrm{~m} / \mathrm{s}$. Berdasarkan data tersebut, responden dominan memilih 'sedikit hangat' sebanyak 10 responden. Di urutan kedua responden memilih 'dingin' sebanyak sembilan responden. Kemudian delapan responden memilih 'netral'. Total responden di hari kedua sebanyak 38 responden. 


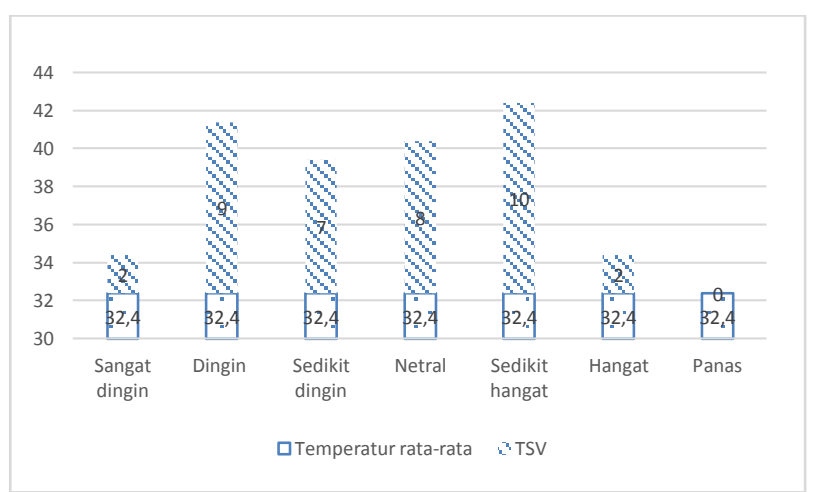

Gambar 5. Temperatur udara rata-rata dan TSV R. 402 pukul 12:45 WIB

\subsection{Data Termal dan Kepuasan Responden di R. 310}

Data grafik berdasarkan Gambar 6, merupakan data temperatur udara rata-rata ruang dalam di R. 310 pada hari ketiga, pukul 12:30 WIB hingga pukul 12:45 WIB. Hasil pengukuran menunjukkan, temperatur udara rata-rata ruang sebesar $28,9^{\circ} \mathrm{C}$, lebih rendah dibandingkan dengan temperatur rata-rata pada hari-hari sebelumnya. Temperatur udara awal di dalam ruangan sebesar $28,8^{\circ} \mathrm{C}$, sedangkan temperatur tertinggi sebesar $29^{\circ} \mathrm{C}$. Kelembaban sebesar 75\%. Kecepatan angin tertinggi sebesar 0,4 m/s terjadi di area jendela luar. Sementara di ruang kelas dan area lainnya tidak ada pergerakan udara atau $0 \mathrm{~m} / \mathrm{s}$. Pada kondisi tersebut, dominan responden memilih 'sedikit hangat' sebanyak 17 responden dan 'netral' sebanyak 14 responden, dari total 38 responden.

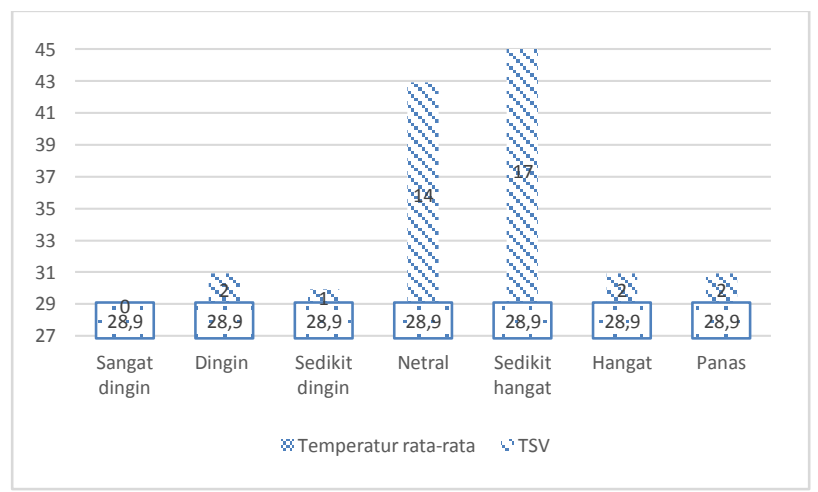

Gambar 6. Temperatur udara rata-rata dan TSV R. 310 pukul 12:30 WIB

\subsection{Data Termal dan Kepuasan Responden di R. 302}

Data grafik berdasarkan Gambar 7, merupakan data temperatur rata-rata ruang dalam di R. 302 pada hari keempat, pukul 10:30 WIB hingga pukul 10:15 WIB. Hasil pengukuran menunjukkan, temperatur udara rata-rata ruang dalam sebesar $28^{\circ} \mathrm{C}$. Temperatur udara awal di dalam ruangan sebesar $27,8^{\circ} \mathrm{C}$, sedangkan temperatur tertinggi sebesar $28^{\circ} \mathrm{C}$. Kelembaban sebesar $80 \%$. Tidak terdapat pergerakan udara di sekitar titik pengukuran. Total responden sebanyak delapan responden yang dikondisikan. Dominan responden memilih 'dingin'. 


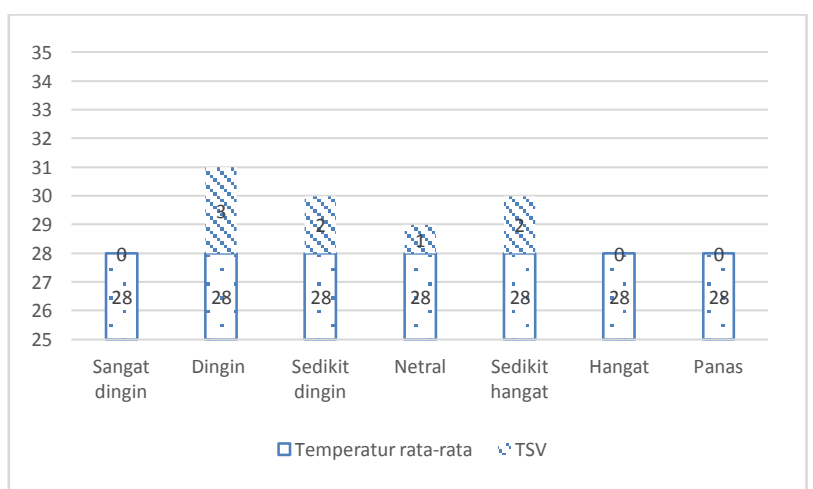

Gambar 7. Temperatur udara rata-rata dan TSV R. 302 pukul 10:30 WIB

\subsection{Regeresi Linier dan Neutral Temperature}

Grafik-grafik di bawah ini menunjukkan analisis regresi linier pada masing-masing ruang. Dalam hal ini dapat diidentifikasi bahwa, kenaikan temperatur di atas $30^{\circ} \mathrm{C}$ cenderung mempengaruhi sensasi termal responden pada skala 0 sampai 1 (netral/nyaman sedikit hangat). Sementara itu, penurunan temperatur di bawah $30^{\circ} \mathrm{C}$ cenderung mempengaruhi sensasi termal responden pada skala -1, 0, 1 (sedikit dingin - netral/nyaman - sedikit hangat). Faktor kecepatan angin dan kelembaban juga dapat mempengaruhi sensasi termal pada skala -1 (Sedikit dingin). NT di R. 402, berturut-turut berada pada posisi : $30,5^{\circ} \mathrm{C}(11: 00), 31,8^{\circ} \mathrm{C}(13: 00), 32,2^{\circ} \mathrm{C}(12: 45)$. NT di R. 310 berapa pada posisi $28,8^{\circ} \mathrm{C}(12: 30)$, dan NT di R. 302 berada pada posisi $27,9^{\circ} \mathrm{C}(10: 30)$.

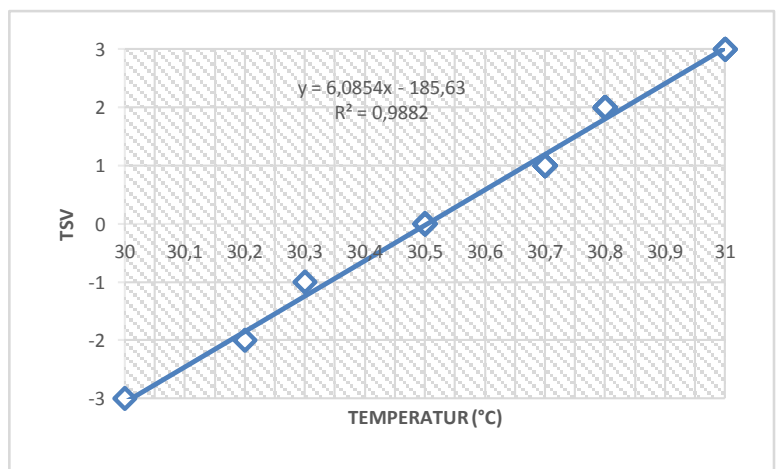

Gambar 8. Analisis regresi linier R.402 pukul 11:00 WIB 


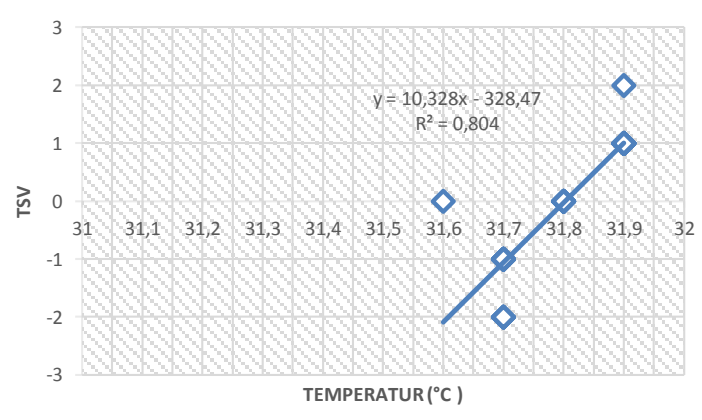

Gambar 9. Analisis regresi linier R.402 pukul 13:00 WIB

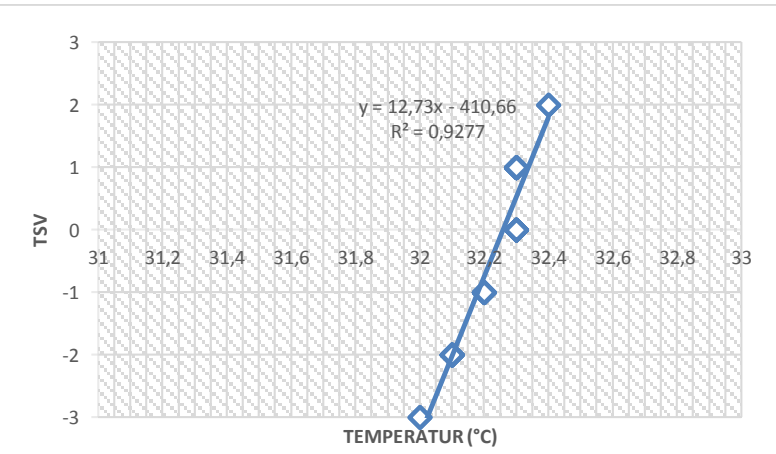

Gambar 10. Analisis regresi linier R.402 pukul 12:45 WIB

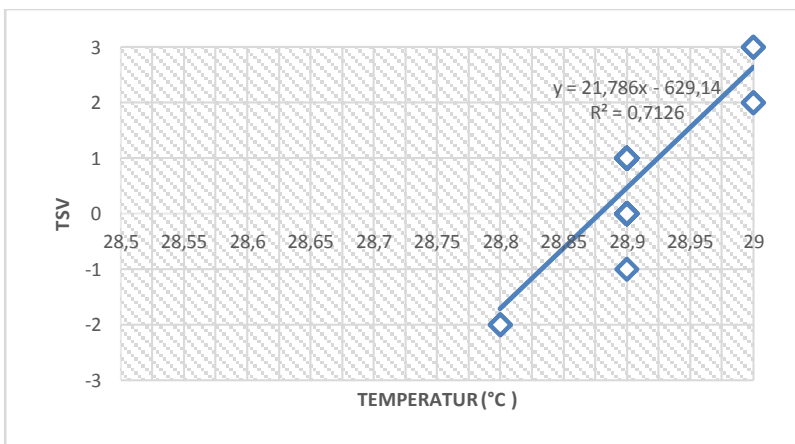

Gambar 11. Analisis regresi linier R.310 pukul 12:30 WIB

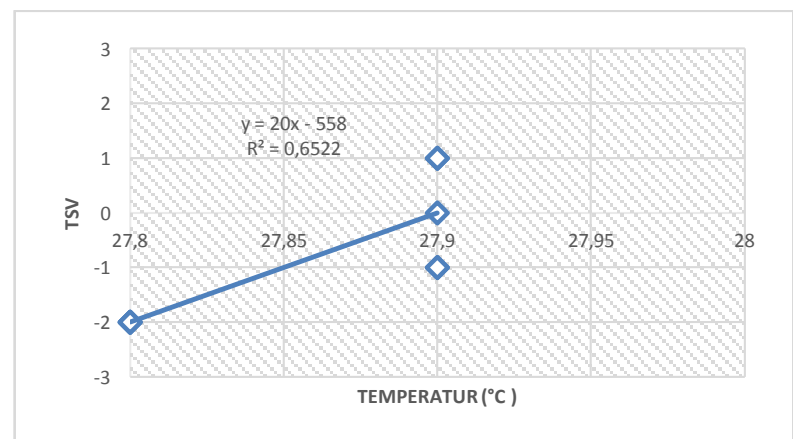

Gambar 12. Analisis regresi linier R.302 pukul 12:30 WIB 


\section{KESIMPULAN}

Hasil simulasi pengukuran termal dan survey sensasi termal yang dirasakan responden dapat memberikan gambaran bahwa, kinerja desain pasif gedung Kampus ITSB melalui penghawaan alami, berkontribusi dalam memberikan kenyamanan bagi pengguna ruang. Hal itu ditunjukkan dengan jumlah responden yang memilih 'netral / nyaman' pada setiap ruang. Namun kinerja tersebut belum optimal, dilihat berdasarkan responden yang memilih 'sedikit hangat'. Perhitungan PMV dan PPD tidak dapat dilakukan, karena pengukuran Mean Radiant Temperatur (MRT) tidak dapat dilaksanakan. Keterbatasan alat ukur dan jumlah unitnya, serta ketersediaan kelas untuk pengukuran menjadi kendala dalam melakukan penelitian ini. Hasil penelitian ini, dapat menjadi penelitian tahap awal untuk pengembangan kajian pada tahap penelitian lanjutan.

\section{UCAPAN TERIMA KASIH}

Penelitian ini merupakan skema penelitian yang didanai oleh Yayasan ITSB. Penulis mengucapkan terima kasih kepada pihak Yayasan ITSB dan Kelompok Keahlian Teknologi Bangunan, Arsitektur ITB yang telah memfasilitasi alat pengukuran.

\section{DAFTAR PUSTAKA}

1) Aniag, B.A., Avenilla, A., Collas, J.J., Regner, P.A., Dela Cruz, E.G. (2017). A Study on Thermal Comfort of Office Employees in the Philippines. The DLSU Research Congress 2017 De La Salle University, Manila, Philippines, June 20 to 22, 2017.

2) ASHRAE. (2013). Thermal Environmental Conditions for Human Occupancy. ANSI/ASHRAE Addendum b to ANSI/ASHRAE Standard 55-2013.

3) Bordass, B., Bromley, K., and Leaman, A. (1993). User and occupant controls in office buildings. BRE Research Report in Building Services.

4) ISO 7730. (1994). International Standard, Moderate Thermal Environments Determination of the PMV and PPD Indices and Specification of the Conditions for Thermal Comfort.

5) Karyono, T.H., Sri, E., Sulistiawan, J.G., Triswanti, Y. (2015). Thermal Comfort Studies in Naturally Ventilated Buildings in Jakarta, Indonesia. Buildings, 5, 917-932.

6) Mishra, A.K., Derks, M.T.H., Kooi, L., Loomans, M.G.L.C., Kort, H.S.M. (2017). Analysing thermal comfort perception of students through the class hour, during heating season, in a university classroom. Building and Environment 125 (2017) 464 $-474$.

7) Nicol, F.J., Humphreys, M.A. Adaptive Thermal Comfort and Sustainable Thermal Standards for Buildings. Oxford Centre for Sustainable Development, School of Architecture, Oxford Brookes University, UK.

8) Omrany, H., Marsono, A.K. 2016. Optimization of Building Energy Performance through Passive Design Strategies. British Journal of Applied Science \& Technology 13(6): 1-16, 2016, Article no.BJAST.23116. 
9) Roetzel, A. (2014). Considerations for occupant behaviour modelling in early design stages. Proceeding of 8th Windsor Conference : Counting the Cost of Comfort in a changing world. Cumberland Lodge, Windsor, UK, 10-13 April 2014. London : Network for Comfort and Energy Use in Building.

10) Sakka, A., Wagner A., Santamouris, M. (2010). Thermal comfort and occupant satisfaction in residential buildings - Results of field study in residential buildings in Athens during the summer period. Proceedings of Conference, Windsor, UK, 9-11 April 2010.

11) The Energy Concervation Center (2010). Energy Conservation for Office Building. Japan. 